\title{
Korelasi Prilaku Personal Hyegiene Saat Menstruasi dengan pH Vagina pada Mahasiswi di Asrama Universitas Muhammadiyah Pringsewu
}

\author{
Cynthia Puspariny, Analia Kunang \\ Universitas Muhammadiyah Pringsewu \\ Email : cynthiapuspariny@umpri.ac.id
}

\begin{abstract}
Abstrak
Kebersihan tubuh pada saat menstruasi juga sangat penting diperhatikan karena dapat memicu terjadinya keputihan. Keputihan biasa terjadi karena $\mathrm{pH}$ (potensial Hidrogen) genetalia yang tidak seimbang. Prilaku Personal hyegiene yang kurang tepat saat menstruasi tidak hanya dilakukan oleh kalangan remaja yang kurang paham mengenai kesehatan reproduksi tapi justru mahasiswa kesehatan memiliki prilaku personal hygiene yang kurang. Tujuan penelitian ini mengetahui korelasi prilaku personal hyegiene saat menstruasi dengan pH Vagina pada Mahasiswi Kesehatan. Jenis penelitian yang digunakan adalah Deskriptif Korelasi dengan desain cross sectional menggunakan Purposive sampling sebanyak 82 sample dilakukan pada bulan Juli - September 2019 di Asrama Universitas Muhammadiyah Pringsewu. Hasil Penelitian Prilaku personal hygiene mayoritas cukup sebanyak 44 responden $(53,7 \%), \mathrm{pH}$ Vagina sebagian besar normal sebanyak 50 responden (61\%) dan hasil uji korelasi rank spearman rho diperoleh nilai $p$ value sebesar 0,000 . Berdasarkan hasil tersebut maka pentingnya edukasi mengenai personal hygiene saat menstruasi dilakukan sebelum atau segera setelah remaja putri menstruasi serta pentingnya pemberian edukasi berulang mengenai personal hygiene pada remaja yang tinggal di asrama.
\end{abstract}

Kata kunci : Personal hyegiene, Menstruasi dan pH Vagina

\begin{abstract}
Personal hygiene in menstruation is also very important because it can trigger vaginal discharge. Leucorrhoea usually occurs due to unbalanced vagina PH (hydrogen potential). Inappropriate personal hygiene behavior in menstruation is not only done by teenagers who do not understand reproductive health, but health students have less personal hygiene behavior. The purpose of this study was to determine the correlation of personal hyegiene behavior during menstruation with Genetalia $\mathrm{pH}$ in Health Students. The research used is descriptive correlation with cross sectional design using purposive sampling of 82 samples conducted in July - September 2019 at the Muhammadiyah Pringsewu University Dermatory. Research Results The majority of personal hygiene behavior is sufficient for 44 respondents $(53.7 \%)$, genetalia $\mathrm{pH}$ is mostly normal as many as 50 respondents $(61 \%)$ and the results of the Spearman rho correlation test obtained a $p$ value of 0.000 . Based on these results, the importance of education on personal hygiene during menstruation is carried out before or immediately after menstruation for young women and the importance of providing repeated education on personal hygiene for adolescents living in dormitories.
\end{abstract}

Key words: Personal hyegiene, Menstruation and The vaginal pH

http://ejournal.urindo.ac.id/index.php/jukmas

Article History : 


\section{PENDAHULUAN}

Aspek kesehatan menstruasi merupakan bagian penting kesehatan reproduksi seorang perempuan, yang tidak hanya meliputi aspek kesehatan fisik, tetapi juga aspek kesehatan mental, spiritual maupun sosial. Kewajiban menjaga kesehatan dan kebersihan terkait menstruasi sering diabaikan. Faktor yang menyebabkannya antara lain karena ketidaktahuan atau karena kurangnya perhatian dalam mengikuti apa yang seharusnya dilakukan.

Berdasarkan hasil SUPAS 2015 bahwa 5,6 \% penduduk lampung usia 10-19 tahun atau pada usia Remaja.[1] WHO (2014) menyebutkan bahwa remaja di dunia hampir $20 \%$ total seluruh penduduk dunia. Jumlah wanita di dunia pada tahun 2013 sebanyak 6,7 milyar jiwa dan yang pernah mengalami keputihan sekitar $75 \%$,sedangkan wanita Eropa pada tahun 2013 sebanyak 739.004.470 jiwa dan yang mengalami keputihan sebesar $25 \%$, dan untuk wanita Indonesia pada. tahun 2013 sebanyak 237.641.326 jiwa dan yang mengalami keputihan berjumlah 75\%. [2] Di Indonesia, prevalensi terjadinya infeksi saluran reproduksiakibat kurangnya hygiene pada organ genitalia masih cukup tinggi, jumlah penderita infeksi saluran reproduksi di Indonesia adalah 90-100 kasus per 100.000 penduduk pertahun [3]

Penyebab utama terjadinya penyakit infeksi saluran reproduksi yaitu: imunitas lemah (20\%), perilaku hygiene saat menstruasi kurang (30\%), dan penggunaan pembalut yang tidak sehat saat menstruasi (50\%) [4] Untuk itu perlu dibiasakan untuk membersihkan organ intim disaat haid dengan cermat. Ketika seseorang lalai dalam menjaga kebersihan organ intim khususnya ketika sedang menstruasi, maka dapat menyebabkan tumbuhnya mikroorganisme yang tidak diharapkan. Kelalaian ini juga bisa menimbulkan bau, infeksi, juga keputihan yang tidak wajar [5]. Pengetahuan tentang kesehatan sistem reproduksi merupakan faktor penting dalam menentukan prilaku hiegienis pada saat menstruasi. Rendahnya pengetahuan tentang kesehatan reproduksi akan memungkinkan perempuan tidak berprilaku higienis pada saat menstruasi dan personal hygeine yang kurang pada remaja akan menimbulkan masalah kesehatan reproduksi. Personal Hygiene Menstruasi adalah kebersihan diri seorang wanita ketika menstruasi yang bertujuan untuk mencegah penyakit serta meningkatkan perasaan sejahtera[6]

Hasil penelitian yang dilakukan terhadap remaja putri yang telah menstruasi di Wilayah Kelurahan Pisangan dan Kelurahan Cirendeu menunjukkan bahwa selama mentruasi siswi yang mandi lebih dari 2 kali sehari ada 54,2 \%, membersihkan vagina dengan air bersih ada 92,3\%, membasuh 
vagina dari depan ke belakang ada 62,7 \%. Penelitian ini sedikit memberi gambaran kepada kita, hal apa saja yang masih harus ditekankan ke remaja putri untuk personal Hygiene mereka [7]. Kebersihan tubuh pada saat menstruasi juga sangat penting diperhatikan karena dapat memicu terjadinya keputihan. Keputihan sering dikaitkan dengan keasaman vagina, karena keputihan biasa terjadi karena $\mathrm{pH}$ (potensial Hidrogen) genetalia yang tidak seimbang. Yang salah satu penyebabnya adalah personal hyegiene yang kurang tepat saat menstruasi.

Genetalia memiliki pH yang asam, yakni sekitar 3,5-4,5. Tingkat keasaman ini memungkinkan vagina untuk memelihara bakteri baik. Jadi tidak diperlukan penggunaan sabun khusus pembersih vagina. Jika mengunakan sabun antiseptik, dapat membahayakan bakteri baik tersebut. Ketika bakteri baik mati, bakteri jahat dan jamur jadi akan lebih mudah bersarang dan dapat meningkatkan pH Vagina. Di Indonesia sendiri 75\% wanita pernah mengalami keputihan minimal satu kali dalam hidupnya dan sebanyak $45 \%$ wanita mengalami keputihan dua kali atau lebih [8]

Prilaku Personal hyegiene yang kurang tepat saat menstruasi tidak hanya dilakukan oleh kalangan remaja yang kurang paham mengenai kesehatan reproduksi, tapi mahasiswa kesehatan tingkat pertama yang juga masih sedikit mempelajari mengenai ilmu kesehatan cenderung memiliki prilaku yang kurang baik dalam personal hiegiene. Peneliti melakukan survey 20 mahasiswi kesehatan semester awal dengan teknik wawancara 11 (55\%) mahasiswi melakukan perawatan yang kurang tepat Ketidaktepatan umumnya pada cara membersihkan genetalia, pemanfaatan pembalut dan cara mencuci dan penggunaan celana dalam. sebanyak 7 mahasiswi dari 11 mahasiswi tersebut sering mengalami keputihan dan perasaan lembab berlebihan pada genetalia. Personal hyegiene saat menstruasi yang tidak benar dapat menyebabkan perubahan vagina menjadi lebih asam sehingga vagina rentan terhadap bakteri hingga dapat menyebabkan keputihan yang meningkatkan perubahan PH Vagina.

Berdasarkan data di atas maka peneliti tertarik untuk meneliti "korelasi prilaku personal hyegiene saat menstruasi dengan $\mathrm{pH}$ Vagina pada Mahasiswi di Asrama Universitas Muhammadiyah Pringsewu".

\section{METODE}

Jenis penelitian yang digunakan adalah Deskriptif Korelasi dengan desain cross sectional. Proses Penelitian berlangsung dari bulan Juli - September 2019. Teknik sampling yang digunakan dalam penelitian ini adalah Purposive sampling sebanyak 82 sample. Variabel independen dalam penelitian ini adalah prilaku personal hyegiene saat menstruasi, Variabel dependen dalam 
penelitian ini adalah $\mathrm{pH}$ Vagina. Instrument penelitian yang digunakan, variable prilaku personal hygiene saat menstruasi instrumen yang digunakan adalah lembar kuisioner sedangkan untuk variabel $\mathrm{pH}$ Vagina dengan menggunakan alat ukur $\mathrm{PH}$ indikator strip yang pengukurannya sesuai prosedur pemeriksaan $\mathrm{pH}$ Vagina. Skala ukur penelitian adalah skala nominal dan ordinal. Pengumpulan data dilakukan pada saat yang sama yaitu sekali pemeriksaan pada menstruasi antara hari ke 3-5 dilakukan pemeriksaan $\mathrm{pH}$ Vagina sekaligus memberikan lembar kuesioner. Penelitian ini menggunakan analisa data statistik dengan uji spearman rank.

\section{HASIL DAN PEMBAHASAN}

Hasil analisis univariat dalam penelitian ini menggambarkan distribusi frekuensi karakteristik responden penelitian, meliputi umur mahasiswa putri dan umur menarche

Tabel 1 Distribusi Frekuensi Berdasarkan

Karakteristik Mahasiswi di Asrama

Universitas Muhammadiyah Pringsewu 2019

\begin{tabular}{lcc}
\hline Karakteristik & Frekuensi & $\begin{array}{c}\text { Persenta } \\
\text { se (\%) }\end{array}$ \\
\hline Umur & $\mathrm{n}$ & $\%$ \\
\hline $18-19$ tahun & 54 & 65,9 \\
$20-21$ tahun & 28 & 34,1 \\
\hline
\end{tabular}

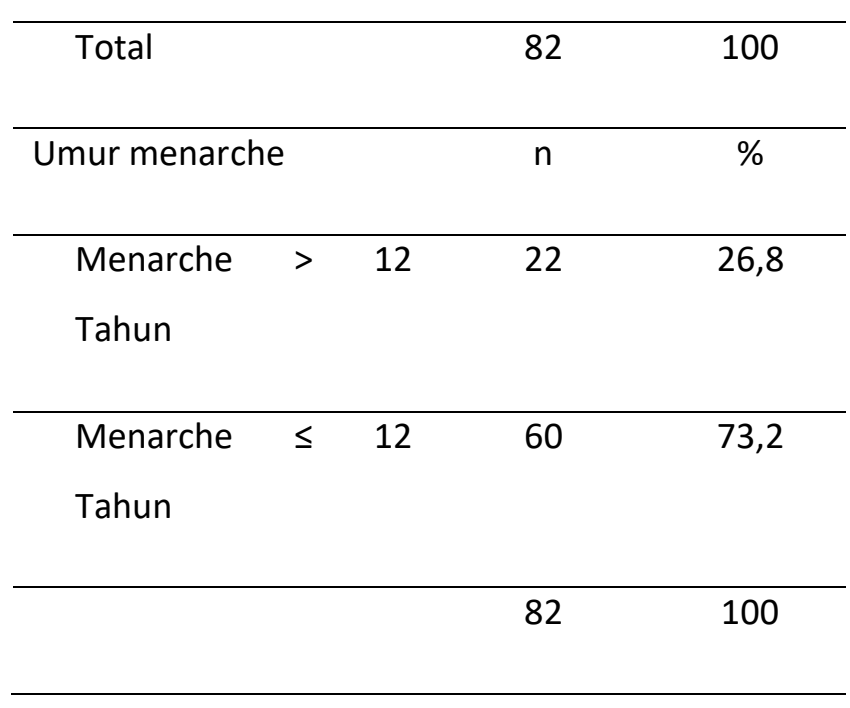

Pada tabel 1 menunjukkan bahwa mahasiswi yang tinggal di asrama Universitas Muhammadiyah Pringsewu berumur 18- 19 Tahun yaitu sebanyak 54 responden (65,9\%). Mahasiswi mayoritas mengalami menarche pada umur $\leq 12$ Tahun yaitu sebanyak 60 responden $(73,2 \%)$

Hasil Riskesdas (2013) menunjukkan bahwarata-rata usia menarche di Indonesia adalah 13 tahun (20,0\%). Departemen Kesehatan Republik Indonesia melaporkan terjadinya penurunan usia menarche di Indonesia, data pada responden yang berusia lebih tua yaitu 55-59 tahun, usia menarche 1314 tahun sekitar $26,5 \%$ dan yang mengalami menarche di bawah usia 12 tahun sebanyak $15,3 \%$, sementara pada responden yang berusia 15-19 tahun mengalami menarche pada usia 13-14 tahun sebanyak 51,3\% dan yang dibawah usia 12 tahun sebanyak 30\%.[9] Usia menarche yang biasa dialami anak perempuan menurut Hendrick (2006) yaitu 
antara 10-16 tahun, dengan rata-rata terjadi pada usia 12,5 tahun. Penurunan usia menarche yang terjadi pada remaja putri di dunia saat ini sangat berkaitan erat dengan beberapa faktor. [10]

Menarche dini merupakan mestruasi pertama yang di alami seorang wanitasubur pada usiadibawah 12 tahun. Kondisi menarchedini karena mendapat produksi hormon estrogenlebih banyak dibanding wanita lain pada umumnya. Menarchedini adalah terjadinya menstruasi sebelum umur 10 tahun yang dikarenakan pubertas dini dimana hormon gonadotrophin diproduksi sebelum anak usia 8 tahun. [11]

Tabel 2 Distribusi Frekuensi Berdasarkan Prilaku Personal hyegiene saat menstruasi

Pada tabel 2 menunjukkan bahwa mahasiswi yang tinggal di asrama Universitas Muhammadiyah Pringsewu berdasarkan prilaku personal hygiene saat menstruasi yang tertinggi yaitu berprilaku personal hygiene kategori cukup sebanyak 44 responden $(53,7 \%)$.

Personal hygiene organ reproduksi merupakan perilaku yang berkaitan dengan tindakan untuk memelihara kesehatan dan upaya menjaga kebersihan pada daerah kewanitaan, perilaku tersebut mencakup; menjaga kebersihan genitalia, seperti membasuh kemaluan dengan air bersih, menggunakan celana yang menyerap keringat, mengganti celana dalam, mengganti pembalut minimal 45 kali sehari, mandi dua kali sehari. [12] Dalam penelitian ini sebagian besar sekitar $53,7 \%$ berprilaku personal Hygiene kategori cukup disebabkan karena seluruh mahasiswi asrama adalah mahasiswa kesehatan yang telah memperoleh teori mengenai Personal Hyegiene.

Hasil tersebut tidak sejalan dengan hasil penelitian yang dilakukan Nikmah 2018 di Pondok Pesantren Al-Munawwir Yogyakarta yang menunjukkan sebagian besar subyek penelitian memiliki personal hygiene habits yang buruk yaitu sebanyak 56 santri (52\%). Sedangkan 50 santri (48\%) memiliki personal hygiene habits yang baik Perbedaan hasil

\begin{tabular}{ccc}
\hline $\begin{array}{c}\text { Prilaku Personal } \\
\text { Higiene }\end{array}$ & $\begin{array}{c}\text { Frekuensi } \\
\text { (n) }\end{array}$ & $\begin{array}{c}\text { Persentase } \\
\text { (\%) }\end{array}$ \\
\hline kurang & 10 & 12,2 \\
cukup & 44 & 53,7 \\
baik & 28 & 34,1 \\
\hline & 82 & 100
\end{tabular}

tersebut dapat terjadi karena beberapa faktor, salah satunya lingkungan dan pengetahuan. Lingkungan di peroleh dari pengalaman selama sebelum tinggal di asrama.[13] Sejalan dengan penelitian Ismi 2018 juga mengungkapkan bahwa dari 40 responden berdasarkan kategori baik, cukup dan kurang yang memiliki prilaku personal hyegiene paling banyak yaitu kategori cukup.[14] 
Sebuah penelitian mengenai prilaku remaja saat sedang menstruasi akan menunjukkan beberapa faktor yang akan mempengaruhi prilaku remaja yaitu Pendidikan orang tua, pengetahuan, sikap, ketersediaan alat pembersih dan adanya dukungan teman sebaya [15] Dalam penelitian ini secara pengetahuan mahasiswa kesehatan cukup baik dikarenakan telah memperoleh materi kuliah tentang anatomi dan fisiologi serta kebutuhan dasar manusia.

\begin{tabular}{ccc}
\multicolumn{3}{c}{$\begin{array}{c}\text { Tabel } 3 \\
\text { Mahasiswi Berdasarkan } \mathbf{p H} \\
\text { Vagina }\end{array}$} \\
\hline pH Vagina & $\begin{array}{c}\text { Frekuensi } \\
\text { (n) }\end{array}$ & $\begin{array}{c}\text { Persentase } \\
\text { (\%) }\end{array}$ \\
\hline Tidak Normal & 32 & 39 \\
Normal & 50 & 61 \\
Total & 82 & 100 \\
\hline
\end{tabular}

Tabel 3 menunjukkan bahwa mahasiswi yang tinggal di asrama Universitas Muhammadiyah Pringsewu $\mathrm{pH}$ Vagina tertinggi yaitu $\mathrm{pH}$ Vagina Normal sebanyak 50 responden (61\%).

Hasil penelitian ini sejalan dengan penelitian Shabrina (2013) menunjukkan hasil bahwa dari 23 ibu hamil memiliki hasil $\mathrm{pH}$ vagina positif basa dengan nilai $\mathrm{pH}>6$ sebanyak 13 orang $(56.5 \%)$, cenderung basa dengan nilai pH 6 sebanyak 5 orang (21.7\%), dan normal dengan nilai $\mathrm{pH} 5$ sebanyak 4 orang (21.7\%).[16] Menurut penelitan Ocviyanti, Rosana, Wibowo (2009) juga menyebutkan dari 492 sampel perempuan Indonesia rata-rata $\mathrm{pH}$ vagina adalah 4.8 dengan median 5 , sedikit lebih basa dibandingkan dengan nilai $\mathrm{pH}$ normal yaitu $<4.5$.[17]

Tabel 4 Korelasi prilaku personal Hygiene

\begin{tabular}{|c|c|c|c|c|c|c|c|c|}
\hline \multirow{3}{*}{$\begin{array}{c}\text { Persona } \\
\text { I } \\
\text { hyegien } \\
\text { e }\end{array}$} & \multicolumn{4}{|c|}{ pH Vagina } & \multirow{2}{*}{\multicolumn{2}{|c|}{ Total }} & \multirow{3}{*}{$\begin{array}{l}\text { Spea } \\
\text { rma } \\
\text { n's } \\
\text { Rho }\end{array}$} & \multirow{3}{*}{$\begin{array}{c}\text { P- } \\
\text { Valu }\end{array}$} \\
\hline & \multicolumn{2}{|c|}{$\begin{array}{l}\text { Tidak } \\
\text { Normal }\end{array}$} & \multicolumn{2}{|c|}{ Normal } & & & & \\
\hline & $n$ & $\%$ & $\mathrm{n}$ & $\%$ & $\mathrm{n}$ & $\%$ & & \\
\hline kurang & 8 & 9,8 & 2 & 2,4 & 19 & 12,2 & & \\
\hline cukup & 19 & 23,2 & 25 & 30,5 & 35 & 53,7 & & \\
\hline baik & 5 & 6,1 & 23 & 28,0 & 28 & 34,1 & 0,38 & 0,0 \\
\hline & 32 & 39,1 & 50 & 59,9 & 82 & $\begin{array}{c}10 \\
0\end{array}$ & 2 & \\
\hline
\end{tabular}

saat menstruasi dengan pH Vagina

Berdasarkan tabel 4. dari hasil analisis korelasi prilaku personal hygiense saat menstruasi kurang dengan $\mathrm{pH}$ Vagina tidak normal $8(9,8 \%)$ mahasiswi dengan prilaku personal hygiene cukup sebagian besar $\mathrm{pH}$ normal $25(30,5 \%)$ dan yang yang prilaku personal hygiene baik sebagian besar dengan pH Vagina normal sekitar 23 (28\%)

Dari hasil analisis hasil uji korelasi rank spearman rho diperoleh nilai $\mathrm{p}$ value sebesar $0,000(p<0,05)$. Maka $\mathrm{H}_{0}$ di tolak yang artinya terdapat korelasi prilaku personal hygiense saat menstruasi dengan $\mathrm{pH}$ Vagina di Asrama Universitas Muhammadiyah Pringsewu 2019.

Berdasarkan analisis dapat disimpulkan bahwa kebiasaan perawatan organ genital 
yang kurang baik seperti tidak membasuh organ kewanitaan dari depan ke belakang, tidak mencukur sebagian rambut kemaluan, tidak mengeringkan organ kewanitaan setelah buang air kecil dan buang air besar, menggunakan celana dalam selain bahan katun, tidak menyiram kloset sebelum digunakan, menggunakan handuk secara bergantian untuk mengeringkan organ kewanitaan, serta tidak mencuci tangan sebelum menyentuh area kewanitaan mendapatkan nilai ph 6 dan $\mathrm{pH}>6$ yaitu dalam kategori curiga basa dan positif basa. Derajat $\mathrm{pH}$ yang asam menyebabkan lactobacillus tumbuh subur dan bakteri patogen tidak bisa hidup [18]

Kondisi $\mathrm{pH}$ basa merupakan daerah yang disukai bakteri candida albicans untuk berkembang biak sehingga mengakibatkan vagina berisiko terkena infeksi yang dapat mengakibatkan komplikasi kehamilan yang membahayakan ibu dan janin. Hasil penelitian ini sejalan dengan Putri, Bening (2013) yang menemukan bahwa perilaku hygiene berhubungan dengan jenis keputihan pada ibu hamil usia gestasi 11-24 minggu di Rumah Sakit Medirossa Cikarang dengan $p$ value 0,005.[19] Hasil penelitian Shabrina, (2013) menemukan bahwa perubahan keasaman vagina berkorelasi dengan kejadian flour albus pada ibu hamil usia gestasi 11-24 minggu di Rumah Sakit Medirossa dengan $p$ value 0.017 . Hasil ini menunjukkan bahwa kebiasaan perawatan organ genital akan mempengaruhi perubahan keasaman vagina.[16]

Apabila perawatan genetalia tidak dilakukan dengan baik, kebersihan dan kelembaban daerah sekitar alat kelamin tidak dijaga, akan memungkinkan berkembangnya bakteri dan jamur yang merugikan, bakteri dan jamur tersebut akan menyebabkan infeksi pada sekitar alat kelamin. Infeksi yang terjadi pada sekitar alat kelamin akan menyebabkan terjadinya keputihan patologi. Upaya yang dapat dilakukan remaja putri agar keputihan tidak memberikan dampak buruk adalah penting sekali bagi remaja putri sadar akan pentingnya personal higiene khususnya vulva higiene[20]. Sehingga dengan melakukan perawatan genetalia yang benar saat menstruasi dapat mengurangi resiko terjadinya Keputihan patologi dan menjaga $\mathrm{pH}$ genetalia dalam keadaan normal.

Dalam penelitian ini sebuah pengalaman yang merupakan suatu kegiatan yang dapat digunakan untuk membentuk pengetahuan seseorang dan dilaksanakan secara berulang kali akan memunculkan sebuah perilaku. Jadi, semakin awal remaja mengalami menstruasi pertama, maka semakin banyak peristiwa yang didapatkan oleh individu. Pengalaman yang baik tersebut pun dapat dikonstruksikan dengan adanya peningkatan tentang sebuah ilmu terkait 
pengetahuan. Dapat digaris bawahi bahwa pengalaman memiliki kontribusi yang cukup besar dalam meningkatkan pengetahuan dalam diri seseorang. sehingga sekalipun reponden adalah mahasiswa kesehatan karena mereka baru mengenyam Pendidikan kesehatan pada tingkat satu diploma maka mereka belum memperoleh pembelajaran mengenai perawatan genetalia yang benar saat menstruasi, merka hanya mengandalkan pengalaman terdahulu saat mereka haid.

\section{SIMPULAN}

Berdasarkan hasil penelitian dan pembahasan, dapat di ambil beberapa kesimpulan sebagai berikut: Prilaku personal hygiene mayoritas cukup sebanyak 44 responden $(53,7 \%)$, pH Vagina sebagian besar normal sebanyak 50 responden (61\%) dan hasil uji korelasi rank spearman rho diperoleh nilai $p$ value sebesar $0,000(p<0,05)$. Maka $H_{0}$ di tolak yang artinya terdapat korelasi prilaku personal hygiense saat menstruasi dengan $\mathrm{pH}$ Vagina.

Saran pengelola Pendidikan sekolah menengah pertama dan sekolah menengeh atas dapat memberikan edukasi mengenai personal hygiene saat menstruasi secara berkesinambungan dan pengelola asrama untuk dapat meningkatkan kesadaran mahasiswi dengan cara memberikan pengarahan dan penjelasan tentang prilaku perawatan Genetalia yang baik serta

\section{DAFTAR PUSTAKA}

[1] SUPAS, "Profil Penduduk Provinsi Lampung," Lampung, 2015.

[2] WHO, "Health for the World's Adolescents: A Second Chance in the Second Decade," Geneva, 2014.

[3] D. K. RI., “Pedoman Perencanaan Pembentukan dan Pengembangan Puskesmas Pelayanan Kesehatan Peduli Remaja di Kabupaten/Kota.," Jakarta, 2014.

[4] Rahmatika, "Pengaruh Pengetahuan dan Sikap Tentang Personal Hygiene Menstruasi Terhadap Tindakan Personal Hygiene Remaja Puteri Pada Saat Menstruasi Di SMK Negeri 8 Medan Tahun 2010.," Sumatera Utara, 2010.

[5] Pribakti, Tips dan Trik Merawat Organ Intim. Jakarta: Sagung Seto.

[6] Aktaruzzaman Md dan Che Kum Clement, "Vocational Education and Training (VET) in Human Resource Development: A Case study of Bangladesh"," Acad. Res. Int., vol. 1, no. 1, 2011.

[7] I. Fitriyah, "Perilaku Higiene Menstruasi pada Remaja Putri di Sekolah Dasar Negeri di Wilayah Puskesmas Pisangan," Jakarta, 2014.

[8] NCBI, "Pubchem compound Summary," 2013.

[9] K. K. R.I., “Laporan Riset Kesehatan Dasar (Riskesdas)," Jakarta, 2013.

[10] H. Hendrik, Problema Haid (Tinjauan Syariat Islam dan Medis). Solo: TigaSerangkai, 
2006.

[11] A. Proverawati, Obesitas dan Gangguan Perilaku Makan pada Remaja.

Yogyakarta: Nuha Medika, 2010.

[12] D. P. Indriastuti, "Hubungan Antara Pengetahuan Kesehatan Reproduksi dengan Perilaku Higienis Remaja Putri Pada Saat Menstruasi," Surakarta, 2009.

[13] H. W. Nikmah, Umi Sa'adatun, "Personal Hygiene Habits dan Kejadian Flour Albus Patologis pada Santriwati PP A;-Munawwir," J. MKMI, vol. 14, no. 1, pp. 36-43., 2018.

[14] I. Sulaikha, "hubungan personal hygiene saat menstruasi dengan pruritus vulvae pada remaja," jombang.

[15] Suryati, "Perilaku kebersihan remaja saat menstruasi," J. Heal. Qual., vol. 3, no. 1, 2013.

[16] Shabrina, "Hubungan Perubahan Keasaman Vagina dengan Kejadian Flour Albus pada Usia Kehamilan 11-24 minggu di RS Medirossa Cikarang.," jakarta, 2013.
[17] W. D.Ocviyanti, Rosana, "Profil Flora Vagina DanTingkat Keasaman Vagina Perempuan Indonesia," Departemen Obstetri Dan Ginekolog indepartemen Mikrobiologi Fakultas Kedokteran UniversitasIndonesia /RsupnDr. CiptoMangunkusumo, Jakarta, Apr. 2009.

[18] B. Moreno, R. \& Park, Cognitive load theory: Historical development and relation to other theories. New York: Cambridge University Press., 2010. [19] B. Putri, "HUBUNGAN PERILAKU HYGIENE ORGAN GENITALIA EKSTERNA DENGAN JENIS KEPUTIHAN PADA IBU HAMIL USIA GESTASI 11-24 MINGGU," Jakarta, 2013.

[20] K. A., "Korelasi Antara Perilaku Vulva Hygine dengan Kejadian Keputihan.," JournalProners, vol. 1, no. 1, p. 34, 2014. 